\title{
Genetic correlations between female fertility and production traits in South African Holstein cattle
}

\author{
M.L. Makgahlela', C.B. Banga ${ }^{1}$, D. Norris ${ }^{2 \#}$, K. Dzama ${ }^{3}$ and J.W. Ng'ambi ${ }^{2}$ \\ ${ }^{1}$ ARC-Livestock Business Division, P/Bag X2, Irene 0062, South Africa \\ ${ }^{2}$ Department of Animal Production, University of Limpopo, P/Bag X1106, Sovenga 0727, South Africa \\ ${ }^{3}$ Department of Animal Science, University of Stellenbosch, P/Bag X1, Matieland 7602, South Africa
}

\begin{abstract}
Female fertility is increasingly gaining importance in national dairy cattle breeding objectives worldwide. In South Africa, there is no routine prediction of breeding values for reproductive performance in dairy cattle and selection is mainly focused on production traits. The objective of this study was to estimate genetic parameters among female fertility traits (age at first calving and calving interval) and first, second and third lactation production traits in South African Holstein cattle to determine the effect that selection on production per se may have on female fertility. Performance records on 40437 South African Holstein cows in 766 herds were used. (Co)variance estimates were obtained by multitrait analysis, using the REML procedure. Heritability estimates were moderate for age at first calving $(0.24 \pm 0.02)$ and low for calving interval $(0.03 \pm 0.01)$. Genetic correlations between age at first calving and yield traits were low to moderately negative, ranging from $-0.17 \pm 0.07$ with second lactation butterfat percentage to $-0.50 \pm 0.05$ with first lactation butterfat yield. Calving interval had moderate to highly positive genetic correlations with yield traits, ranging from $0.37 \pm 0.10$ with second lactation milk yield to $0.69 \pm 0.06$ with first lactation milk yield. Correlations between female fertility and butterfat and protein percentages across all lactations, were close to zero. The observed antagonistic relationship between calving interval and production traits highlights the need to include calving interval in breeding objectives for South African Holstein cattle.
\end{abstract}

Keywords: Age at first calving, calving interval, milk yield

" Corresponding author. E-mail: norrisd@ul.ac.za

\section{Introduction}

Female fertility is one of the most economically important traits in dairy cattle. Reproductive failure causes economic losses due to reduced production as a result of prolonged calving intervals (Van Arendonk et al., 1989; Boichard et al., 1997; Olori et al., 2002), increased insemination costs, reduced returns from calves born and higher replacements costs (Bagnato \& Oltenacu, 1994). Fertility problems are the most common reasons for culling in dairy cattle (Philipsson, 1981). Culling for low reproduction rate as a proportion of disposal reasons has been reported to account for 25\% in France (Colleau \& Moureaux, 1999). Esselmont \& Kossaibati (1997) showed that the primary reason for culling dairy cattle in the UK was failure to conceive, which accounted for $44 \%$ of culls in first lactation animals. Depending on the level of production, increasing calving interval (CI) by one day costs the breeder about 1.8 US dollars in Ireland, without accounting for the costs of higher culling due to poorer fertility (Esselmont et al., 2001).

Female fertility has been neglected in the past in most dairy cattle genetic improvement programmes worldwide, mainly because fertility traits are known to exhibit a low heritability (Raheja et al., 1989; Grosshans et al., 1997; Pryce et al., 1998; Kadarmideen, 2004). Despite their low heritability, fertility traits have been shown to have high additive genetic variation (Philipsson, 1981; Hermas et al., 1987; Raheja et al., 1989; Oltenacu, 1991; Grosshans et al., 1997; De Jong, 1998) and therefore, increasing the amount of information available for use in genetic evaluation may facilitate their improvement through selection. Traditionally selection pressure has been applied mainly on yield traits worldwide. Because of antagonistic genetic correlations, intense single-trait selection for production is expected to cause a decline in fertility (Van Arendonk et al., 1989; Frick \& Lindhe, 1991; Bagnato \& Oltenacu, 1994; Campos et al., 1994; Hoekstra et al., 1994; Pryce et al., 1997; 2004; De Jong, 1998; Ojango \& Pollot, 2001; Nilfrorooshan \& Edriss, 2004; Kadarmideen, 2004; VanRaden et al., 2004). 
To maintain or recover a high fertility in modern dairy cows calls for a two-pronged approach, involving both inclusion of fertility in broader breeding objectives and adjustment to management practices (Pryce et al., 2004). Selection for fertility traits requires identifying suitable traits that can be used as selection criteria (Haile-Mariam et al., 2003). Kadarmideen \& Simm (2002) observed an increase in economic returns of up to $38 \%$ by adding CI to the UK total merit index.

Breeding programmes for dairy cattle in South Africa have been based primarily on increased milk production (Banga \& Rautenbach, 1999). During the period 1982 to 2001, the average genetic merit for production traits increased remarkably in the major dairy cattle breeds (Hallowell \& Mostert, 2001). These trends are probably due to the fact that yield is the main selection criterion for most South African producers.

The objectives of this study were: a) to estimate genetic parameters of female fertility traits (age at first calving (AFC) and CI) and, first, second and third lactation production traits; and b) to determine the effect that selection on production per se may have on female fertility.

\section{Materials and Methods}

The fertility traits considered were AFC and CI. Calving interval in different lactations was treated as the same repeated trait. Production traits were lactation milk yield (MLKY), butterfat yield (BFATY), protein yield (PROTY), butterfat percentage (BFPCT) and protein percentage (PPCT). Production in different lactations was treated as different traits. Only first, second and third lactation production traits were considered.

The original data set consisted of performance records of 200319 Holstein cows calving between 1980 and 2005, and, pedigree information of 885567 animals. All data were obtained from the Integrated Registration and Genetic Information System (Intergis) of South Africa. Records with unknown birth and calving dates were deleted. Age at calving within each lactation was restricted to remove outliers, using the following ranges, as used by Mostert et al. (2006): 20-42 months for lactation 1, 30-54 months for lactation 2 and 40-67 months for lactation 3. Records with CI less than 300 days or greater than 600 days were also discarded. The data were edited further to remove lactation records that were incomplete and unusable for genetic evaluations, according to the conditions used by the National Dairy Cattle Performance Testing Scheme of South Africa (National Dairy Cattle Performance Testing Scheme, 1999). Further edits were done to remove milk yields less than $1000 \mathrm{~kg}$ or greater than $30000 \mathrm{~kg}$; butterfat percentages less than $2 \%$ or greater than $9 \%$ and protein percentages less than $2 \%$ or greater than $6 \%$.

Two calving seasons were defined as summer (October - March) and winter (April - September) (Mostert et al., 2006). Each CI and AFC observation was assigned to a calving herd-year-season contemporary group. Cows with production records were also assigned to herd-year-season of calving contemporary groups. Contemporary groups with less than five animals or less than two sires were removed. Each cow had to have a first lactation record to take into account the selection of cows which made subsequent records. Finally, a random subset of data was extracted, based on contemporary group, to fit available computer capacity. A pedigree file containing all animals in the data set, going back four generations, was constructed. The pedigree file contained 97320 cows, daughters of 4194 sires and 60183 dams. Table 1 shows the structure of the data set.

Descriptive statistics of all traits were computed using the Proc Means procedure of the Statistical Analysis System (SAS, 1998). An Analysis of Variance was carried out using the General Linear Model (GLM) procedure of SAS (1998) to determine non-genetic factors affecting each trait, in order to determine the effects that should be included in the models for variance component estimation. The effects tested were herd-year-season of calving, linear and quadratic effects of calving age, and previous CI (only fitted for second and third lactation production traits). All these effects were significant $(\mathrm{P}<0.05)$ except the quadratic effect of calving age, which was not significant for all production traits.

The Variance Component Estimation-Restricted Maximum Likelihood (VCE-REML) Version 5.0 programs of Groeneveld et al. (2003) were used to estimate variance and covariance components. A multitrait analysis of all 17 traits simultaneously was not computationally feasible. For this reason, a series of four-trait analyses (one fertility trait and three production traits) was performed. The four-trait animal model equations 1 and 2, in matrix notation, were used respectively for the analysis of AFC and CI, each with three production traits. 
Table 1 Structure and descriptive statistics of data

\begin{tabular}{|c|c|c|c|c|c|c|c|c|}
\hline Trait & $\begin{array}{l}\text { No of } \\
\text { Records }\end{array}$ & HYS & Sires & Herds & Min & Max & Mean & $\sigma_{p}$ \\
\hline AFC (months) & 9336 & 760 & 1263 & 470 & 20 & 41 & 28 & 4 \\
\hline CI (days) & 16183 & 899 & 2029 & 604 & 300 & 600 & 396 & 58 \\
\hline \multicolumn{9}{|l|}{$1^{\text {st }}$ lactation } \\
\hline MLKY1 (kg) & 20618 & 1269 & 1862 & 536 & 1126 & 15572 & 6802 & 1969 \\
\hline BFATY1 (kg) & 20593 & 1269 & 1861 & 536 & 40 & 580 & 239 & 72 \\
\hline PROTY1 (kg) & 20592 & 1269 & 1862 & 536 & 40 & 497 & 216 & 61 \\
\hline BFPCT1 (\%) & 20593 & 1269 & 1861 & 536 & 2.00 & 5.77 & 3.53 & 0.39 \\
\hline PРCT1 (\%) & 20593 & 1269 & 1862 & 536 & 2.46 & 4.54 & 3.18 & 0.20 \\
\hline \multicolumn{9}{|l|}{$2^{\text {nd }}$ lactation } \\
\hline MLKY2 (kg) & 8704 & 672 & 1214 & 248 & 1876 & 17635 & 8095 & 2230 \\
\hline BFATY2 (kg) & 8661 & 671 & 1209 & 248 & 67 & 691 & 282 & 83 \\
\hline PROTY2 (kg) & 8653 & 671 & 1208 & 248 & 60 & 540 & 255 & 69 \\
\hline BFPCT2 (\%) & 8661 & 671 & 1209 & 248 & 2.03 & 5.42 & 3.51 & 0.40 \\
\hline РPCT2 (\%) & 8653 & 671 & 1208 & 248 & 2.58 & 4.06 & 3.18 & 0.20 \\
\hline \multicolumn{9}{|l|}{$3^{\text {rd }}$ lactation } \\
\hline MLKY3 (kg) & 4112 & 396 & 829 & 154 & 2025 & 28391 & 8695 & 2234 \\
\hline BFАTY3 (kg) & 3948 & 390 & 798 & 149 & 72 & 797 & 302 & 72 \\
\hline PROTY3 (kg) & 3942 & 390 & 798 & 151 & 73 & 567 & 271 & 73 \\
\hline ВFРСТ3 (\%) & 3948 & 390 & 798 & 149 & 2.01 & 5.50 & 3.49 & 0.39 \\
\hline РРСТ3 (\%) & 3942 & 390 & 798 & 151 & 2.51 & 4.34 & 3.15 & 0.19 \\
\hline
\end{tabular}

AFC - age at first calving; CI - calving interval; MLKY - lactation milk yield; BFATY - butterfat yield; PROTY - protein yield, BFPCT - butterfat percentage; PPCT - protein percentage

HYS - herd-year-season, Min - minimum value, Max - maximum value, $\sigma_{\mathrm{p}}$ - standard deviation

$$
\begin{aligned}
& {\left[\begin{array}{l}
y_{1} \\
y_{2} \\
y_{3} \\
y_{4}
\end{array}\right]=\left[\begin{array}{l}
X_{1} b_{1}+Z_{1} u_{1} \\
X_{2} b_{2}+Z_{2} u_{2} \\
X_{3} b_{3}+Z_{3} u_{3} \\
X_{4} b_{4}+Z_{4} u_{4}
\end{array}\right]+\left[\begin{array}{l}
e_{1} \\
e_{2} \\
e_{3} \\
e_{4}
\end{array}\right]} \\
& {\left[\begin{array}{l}
y_{1} \\
y_{2} \\
y_{3} \\
y_{4}
\end{array}\right]=\left[\begin{array}{l}
X_{1} b_{1}+Z_{1} u_{1} \\
X_{2} b_{2}+Z_{2} u_{2} \\
X_{3} b_{3}+Z_{3} u_{3} \\
X_{4} b_{4}+Z_{4} u_{4}+W p
\end{array}\right]+\left[\begin{array}{l}
e_{1} \\
e_{2} \\
e_{3} \\
e_{4}
\end{array}\right]}
\end{aligned}
$$

where: $y_{1}, y_{2}$ and $y_{3}$ are vectors of observations for three production traits; $y_{4}$ in Equation 1 is a vector of observations for AFC and $\mathrm{y}_{4}$ in Equation 2 is a vector of observations for $\mathrm{CI} ; \mathrm{X}_{1}, \mathrm{X}_{2}, \mathrm{X}_{3}$ are incidence matrices relating observations on production traits to fixed environmental effects (calving HYS, linear calving age and $\mathrm{CI}$ ); $\mathrm{X}_{4}$ in equation 1 is an incidence matrix relating AFC observations to fixed environmental effects (calving HYS); $\mathrm{X}_{4}$ in equation 2 is an incidence matrix relating CI observations to fixed environmental effects (calving HYS, linear and quadratic calving age); $b_{1}, b_{2}, b_{3}$ and $b_{4}$ are vectors of fixed effects; $Z_{1}, Z_{2}, Z_{3}$ and $Z_{4}$ are incidence matrices relating observations to random animal effects; $u_{1}, u_{2}$, $\mathrm{u}_{3}$ and $\mathrm{u}_{4}$ are vectors of additive genetic effects of the animal; $\mathrm{W}$ is the incidence matrix relating observations 
to permanent animal environmental effects; $p$ is the vector of random permanent animal environmental effects; $\mathrm{e}_{1}, \mathrm{e}_{2}, \mathrm{e}_{3}$ and $\mathrm{e}_{4}$ are vectors of random residual effects.

\section{Results}

Table 1 provides a summary of the data and descriptive statistics of all traits in the data set used for parameter estimation. The average CI and AFC were respectively 396 days and 28 months. Phenotypic standard deviations were 58 days and four months respectively for CI and AFC. The means for yield traits ranged from $6802 \mathrm{~kg}, 239 \mathrm{~kg}$ and $216 \mathrm{~kg}$, for MLKY1, BFATY1 and PROTY1, respectively, to $8695 \mathrm{~kg}$, $302 \mathrm{~kg}$ and $271 \mathrm{~kg}$ for MLKY3, BFATY3 and PROTY3, respectively. Phenotypic standard deviations were in the range $1969 \mathrm{~kg}, 72 \mathrm{~kg}$ and $61 \mathrm{~kg}$ for MLKY1, BFATY1 and PROTY1, respectively, to $2234 \mathrm{~kg}, 72 \mathrm{~kg}$ and $73 \mathrm{~kg}$ for MLKY3, BFATY3 and PROTY3, respectively. The phenotypic means for percentage traits ranged from 3.49\% and 3.15\% for BFPCT3 and PPCT3 respectively, to 3.53\% and 3.18\% for BFPCT1 and PPCT1.

Heritability estimates for all traits are given in Table 2. Age at first calving had a moderate heritability (0.24) while the estimate for CI was low (0.03). Production traits were moderate to highly heritable, with estimates ranging from 0.19 (BFATY2) to 0.65 (PPCT1). Estimates were highest in first lactation for all traits but there was no observable trend across lactations.

Table 2 Estimates of heritabilities for fertility and first, second and third lactation production traits

\begin{tabular}{cc}
\hline Trait & Heritability \pm s.e. \\
\hline AFC & $0.24 \pm 0.02$ \\
CI & $0.03 \pm 0.01$ \\
$1^{\text {st }}$ lactation & $0.33 \pm 0.02$ \\
MLKY1 & $0.24 \pm 0.02$ \\
BFATY1 & $0.28 \pm 0.02$ \\
PROTY1 & $0.46 \pm 0.02$ \\
BFPCT1 & $0.65 \pm 0.02$ \\
PPCT1 & \\
$2^{\text {nd }}$ lactation & $0.25 \pm 0.02$ \\
MLKY2 & $0.19 \pm 0.02$ \\
BFATY2 & $0.24 \pm 0.02$ \\
PROTY2 & $0.35 \pm 0.03$ \\
BFPCT2 & $0.55 \pm 0.02$ \\
PPCT2 & \\
$3^{\text {rd }}$ lactation & $0.25 \pm 0.03$ \\
MLKY3 & $0.22 \pm 0.03$ \\
BFATY3 & $0.26 \pm 0.03$ \\
PROTY3 & $0.36 \pm 0.04$ \\
BFPCT3 & $0.47 \pm 0.03$ \\
PPCT3 & \\
& \\
\hline
\end{tabular}

AFC - age at first calving; CI - calving interval; MLKY - lactation milk yield; BFATY - butterfat yield; PROTY - protein yield, BFPCT - butterfat percentage; PPCT - protein percentage 
Estimates of genetic correlations between AFC and milk production traits are given in Table 3. All genetic correlations between AFC and yield traits were negative, while correlations between AFC and percentage traits were essentially zero, except that with third lactation BFPCT (0.14). Genetic correlations between AFC and yield traits decreased with increase in parity. Estimates of genetic correlations between CI and milk production traits are given in Table 3 . Positive and moderate to high genetic correlations were observed between CI and yield traits, ranging from 0.37 with second lactation MLKY to 0.69 with first lactation MLKY. Genetic correlations between yield traits and CI were highest in first parity and lowest in second parity. Correlations between CI and percentage traits were low and close to zero for lactations 2 and 3.

Table 3 Estimates of genetic correlations fertility and first, second and third lactation production traits

\begin{tabular}{ccc}
\hline Traits & Age at first calving & Calving interval \\
\hline $1^{\text {st }}$ lactation production & & \\
MLKY1 & $-0.43 \pm 0.05$ & $0.69 \pm 0.06$ \\
BFATY1 & $-0.50 \pm 0.05$ & $0.66 \pm 0.06$ \\
PROTY1 & $-0.49 \pm 0.05$ & $0.68 \pm 0.06$ \\
BFPCT1 & $0.03 \pm 0.02$ & $-0.17 \pm 0.07$ \\
PPCT1 & $0.03 \pm 0.02$ & $-0.16 \pm 0.06$ \\
$2^{\text {nd }}$ lactation production & & \\
MLKY2 & $-0.35 \pm 0.05$ & $0.37 \pm 0.10$ \\
BFATY2 & $-0.35 \pm 0.06$ & $0.44 \pm 0.10$ \\
PROTY2 & $-0.39 \pm 0.04$ & $0.41 \pm 0.10$ \\
BFPCT2 & $-0.02 \pm 0.07$ & $0.05 \pm 0.01$ \\
PPCT2 & $-0.05 \pm 0.05$ & $0.03 \pm 0.01$ \\
$3^{\text {rd }}$ lactation production & & \\
MLKY3 & $-0.29 \pm 0.08$ & $0.52 \pm 0.10$ \\
BFATY3 & $-0.17 \pm 0.09$ & $0.50 \pm 0.10$ \\
PROTY3 & $-0.25 \pm 0.08$ & $0.50 \pm 0.10$ \\
BFPCT3 & $0.14 \pm 0.03$ & $0.06 \pm 0.08$ \\
PPCT3 & $0.08 \pm 0.03$ & $-0.03 \pm 0.04$
\end{tabular}

MLKY - lactation milk yield; BFATY - butterfat yield; PROTY - protein yield,

BFPCT - butterfat percentage; PPCT - protein percentage

\section{Discussion}

The primary objective of this study was to estimate genetic parameters among female fertility and production traits, to determine the effect that selection on production per se may have on female fertility. Yields in different lactations were treated as different traits in order to determine whether correlations were constant across lactations.

The heritability of AFC was higher than estimates obtained for Holstein-Friesian cattle in the USA (Seykora \& MacDaniel, 1983). Rege (1991) and Ojango \& Pollot (2001), however, reported higher heritability estimates in Kenyan Holstein-Friesian cattle. The discrepancies could be due to differences in genetic variation among the populations, differences in statistical models used for analysis or varying reactions of the same breed to different environmental conditions. Heritability estimates for production traits were comparable to those obtained previously for the South African Holstein population (Tesfa, 2002) and 
generally within the range reported in the literature (Pryce et al., 1998; Lobo et al., 2000; Haile-Mariam, 2003; Kadarmideen, 2004). The moderate heritabilities for AFC and production traits indicate that there is potential for improvement of these traits through selection. The low heritability estimate for CI is in agreement with many other studies on Holstein-Friesian cattle (Hoekstra et al., 1994; Veerkamp et al., 2001; Olori et al., 2002; Wall et al., 2003; 2004). However, higher estimates were reported for Holstein-Friesian cattle in Kenya (Rege, 1991; Ojango \& Pollot, 2001) and Florida, USA (Campos et al., 1994).

The low heritability estimate for CI indicates that significant improvement through selection is attainable only through enhanced accuracy of selection by, for example, incorporating information on correlated traits. Traits such as body condition score, certain linear type traits, milk progesterone and milk urea nitrogen have been shown to be genetically correlated with fertility (Dadati et al., 1986; Darwash et al., 1999; Melendez et al., 2000; Pryce et al., 2000; Royal et al., 2000; 2002; Dechow et al., 2001; Godden et al., 2001; Veerkamp et al., 2001; Gutierrez et al., 2002; Berry et al., 2003; Wall et al., 2003; 2005; HaileMariam et al., 2004; Kadarmideen, 2004).

Estimates of genetic correlations between fertility traits (AFC and CI) and milk production traits from most previous studies were only based on first lactation production (Rege, 1991; Pryce et al., 2000; Ojango \& Pollot, 2001; Campos et al., 1994; Hoekstra et al., 1994). Genetic correlations observed between AFC and milk yield were higher and more negative than estimates observed in Kenyan Holstein-Friesian cattle by Rege (1991). Across all lactations, genetic correlations between AFC and milk yield were, however, smaller than estimates obtained by Ojango \& Pollot (2001), also in Holstein-Friesian cattle in Kenya. Correlations were highest in first parity and lowest in third parity, indicating a strong relationship between these traits in early parities. The negative association between AFC and yield traits indicates a favourable effect of yield traits on age at first calving. Thus, selection for increased yield may result in a correlated improvement in AFC. The stress of increased yield may, however, overcome the genetic merit for improved fertility, especially post-partum reconception (Rege, 1991). Correlations between AFC and percentage traits were mostly close to zero, except that between AFC and third lactation butterfat (0.14), which was similar to that reported by Rege (1991). This indicates that selection for butterfat percentage is detrimental to AFC.

The genetic correlations between CI and yield traits were moderate to high and positive, in agreement with most literature estimates for Holstein-Friesian cattle (Hoekstra et al., 1994; Pryce et al., 1997; 1998; 2000; Ojango \& Pollot, 2001; Veerkamp et al., 2001). Smaller estimates were, however, reported for Holstein-Friesian cattle in Kenya by Rege (1991) and in the United Kingdom (Wall et al., 2003). Genetic correlations between CI and yield traits were highest in first parity, indicating that post-partum fertility is mostly associated with first lactation yield. A positive genetic correlation between CI and yield indicates that animals with high genetic merit for milk, butterfat and protein yield would tend to have longer calving intervals, indicating antagonism between CI and yield traits. Similar antagonistic relationships have been reported in studies between most fertility traits and production (Hoekstra et al., 1994; Veerkamp et al., 2001; Berry et al., 2003; Wall et al., 2003). Due to this fact, intense selection for yield, without regard to fertility has led to deterioration in reproductive performance in most countries (Van Arendonk et al., 1989; Frick \& Lindhe, 1991; Bagnato \& Oltenacu, 1994; Campos et al., 1994; Hoekstra et al., 1994; De Jong, 1998; Pryce et al., 1997; Ojango \& Pollot, 2001; Kadarmideen, 2004; VanRaden et al., 2004). The genetic correlations between CI and protein and butterfat percentage traits were low for lactation 1 and close to zero for lactations 2 and 3, suggesting that there is low genetic association between CI and percentage traits.

\section{Conclusions}

The heritability estimate for age at first calving and production traits indicate that these traits can be improved genetically through selection in the South African Holstein population. Selection on CI is, however, likely to achieve slow progress, due to its low heritability. There is a need to enhance the accuracy of selection on CI by increasing information used for its evaluation.

Findings indicate favourable genetic relationships between age at first calving and yield in South African Holsteins. However, unfavourable genetic associations were found between calving interval and yield traits. A correlated decline in post partum cow fertility (increased CI) is likely to result from selection on yield, without regard to fertility. Thus, female fertility should be included in the breeding objective for South African Holstein cattle. 


\section{Acknowledgements}

Authors would like to thank the Integrated Registration and Genetic Information System for supplying the data and the Agricultural Research Council for computational resources.

\section{References}

Bagnato, A. \& Oltenacu, P.A., 1994. Phenotypic evaluation of fertility traits and their association with milk production of Italian Friesian cattle. J. Dairy Sci. 77, 874-882.

Banga, C.B. \& Rautenbach, L., 1999. Genetic progress from 1980 to 1999. Annual Report National Dairy Cattle Performance Testing Scheme South Africa. ARC. Animal Improvement Institute. pp. 6-11.

Berry, D.P., Buckley, F., Dillon, P., Evans, R.D., Rath, M. \& Veerkamp, R.F., 2003. Genetic relationships among body condition score, body weight, milk yield and fertility in dairy cows. J. Dairy Sci. 86, 2193-2204.

Boichard, D., Barbart, A. \& Briend, M., 1998. Genetic evaluation for female fertility in French dairy cattle. Interbull Bull. 18, 99-101.

Campos, M.S., Wilcox, C.J., Becerril, C.M. \& Diz, A., 1994. Genetic parameters for yield and reproductive traits of Holstein and Jersey cattle in Florida. J. Dairy Sci. 77, 867-873.

Colleau, J. \& Moureaux, S., 1999. Constructing the selection objective of the French Holstein population. Interbull Bull. 23, 41-46.

Dadati, E., Kennedy, B.W. \& Burnside, E.B., 1986. Relationship between conformation and calving interval in Holstein cows. J. Dairy Sci. 69, 3112-3119.

Darwash, A.O., Lamming, G.E. \& Woolliams, J.A., 1999. The potential for identifying heritable endocrine parameters associated with fertility in post-partum dairy cows. Anim. Sci. 68, 333-347.

Dechow, C.D., Rogers, G.W. \& Clay, J.S., 2001. Heritabilities and Correlations among body condition scores, production traits and reproductive performance. J. Dairy Sci. 84, 266-275.

De Jong, G., 1998. Index for daughters' fertility in the Netherlands. Interbull Bull. 18, 102-105.

Esselmont, R.J. \& Kossaibati, M.A., 1997. Culling in 50 dairy herds in England. Vet. Rec. 140, 36-39.

Esselmont. R.J., Kossaibati, M.A. \& Allock, J., 2001. Economics of fertility in dairy cows. Fertility in the High-Producing Dairy cow. Brit. Soc. Anim. Sci., Ed. Diskin, M.G., Occasional Publication. 26, 19-29 (Cited by Veerkamp et al., 2001 and Olori et al., 2002).

Frick, A. \& Lindhe, B., 1991. Relationship of fertility to milk yield in Swedish cattle. J. Dairy Sci. 74, 264-268.

Godden, S.M., Kelton, D.F., Lissemore, K.D., Walto, J.S., Leslie, K.E. \& Lumsden, J.H., 2001. Milk urea testing as a tool to monitor reproductive performance in Ontario dairy herds. J. Dairy Sci. 84, 1397-1406.

Groeneveld, E., Kovac, M \& Garcia-Cortex, A., 2003. REML VCE a multi model restricted maximum likelihood (co)variance component estimation package version 5. User's guide.

Grosshans, T., Xu, Z.Z., Burton, L.J., Johnson, D.L. \& Macmillan, K.L., 1997. Performance and genetic parameters for fertility of seasonal dairy cows in New Zealand. Livest. Prod. Sci. 51, 41-51.

Gutierrez, J.P., Alvarez, I., Fernandez, I., Royo, L.J., Diez, J. \& Goyache, F., 2002. Genetic relationship between calving date, calving interval and type traits in beef cattle. Livest. Prod. Sci. 78, 215-222.

Haile-Mariam, M., Morton, J.M. \& Goddard, M.E., 2003. Estimates of genetic parameters for fertility traits of Australian Holstein-Friesian cattle. Anim. Sci. 76, 35-42.

Haile-Mariam, M., Bowman, P.J. \& Goddard, M.E., 2004. Genetic and environmental relationship among calving interval, survival, persistency of milk yield and somatic cell count in dairy cattle. Anim. Sci. 80, 189-200.

Hallowell, G.J. \& Mostert, B.E., 2001. Genetic progress from 1982 to 2001. Annual Report. South African National Animal Improvement Scheme. ARC. Animal improvement Institute. Annual report. 21, 4-6.

Hermas, S.A., Young, C.W. \& Rust, J.W., 1987. Genetic relationships and additive genetic variation of productive and reproductive traits in Guernsey dairy cattle. J. Dairy Sci. 70, 1252-1257.

Hoekstra, J., Van der Lugt, A.W., Van der Werf, J.H.J. \& Ouweltjies, W., 1994. Genetic parameters for milk production and fertility traits in upgraded dairy cattle. Livest. Prod. Sci. 40, 225-232.

Kadarmideen, H.N., 2004. Genetic correlations among body condition score, somatic cell score, milk production, fertility and conformation traits in dairy cows. Anim. Sci. 79, 191-201. 
Kadarmideen, H.N. \& Simm, G., 2002. Selection responses expected from index selection including disease resistance fertility and longevity in dairy cattle. In: Proceedings, $7^{\text {th }}$ World Congr. Gen. Appl Livest. Prod. Montpellier, France.

Lobo, R.N.B., Madalena, F.E. \& Vieira, A.R., 2000. Average estimates of genetic parameters for beef and dairy cattle in tropical regions. Anim. Breed. Abstr. 68, 433-462.

Melendez, P., Donovan, A. \& Hernandez, J., 2000. Milk urea nitrogen and infertility in Florida Holstein cows. J. Dairy Sci. 83, 459-463.

Mostert, B.E., Theron, H.E. \& Kanfer, F.H.J., 2006. Test-day model for South African for participation in the international evaluations. S. Afr. J. Anim. Sci. 36, 58-70.

National Dairy Cattle Performance Testing Scheme, 1999. General features concerning the performance testing scheme data. Agricultural Research Council. Animal Improvement Institute, South Africa. Annual Report. pp. 20-28.

Nilfrorooshan, M.A. \& Edriss, M.A., 2004. Effect of age at first calving on some productive and longevity traits in Iranian of the Isfahan Province. J. Dairy Sci. 87, 2130-2135.

Ojango, J.M.K. \& Pollot, G.E., 2001. Genetics of milk yield and fertility traits in Holstein-Friesian cattle on large-scale Kenyan farms. J. Dairy Sci. 79, 1742-1750.

Olori, V.E., Meuwissen, T.H.E. \& Veerkamp, R.F., 2002. Calving interval and survival breeding values as a measure of cow fertility in a pasture-based production system with seasonal calving. J. Dairy Sci. 85, 689-696.

Oltenacu, P.A., 1991. Relationship of fertility to milk yield in Swedish cattle. J. Dairy Sci. 74, 264-268.

Philipsson, J., 1981. Genetic aspects of female fertility in dairy cattle. Livest. Prod. Sci. 8, 307-319.

Pryce, J.E., Veerkamp, R.F., Thompson, R., Hill, W.G. \& Simm, G., 1997. Genetic aspects of common health disorders and measures of fertility in Holstein Frisian Dairy cattle. Anim. Sci. 65, 353-360.

Pryce, J.E., Esslemont, R.J., Thompson, R., Veerkamp, R.F., Kossaibati, M.A. \& Simm, G., 1998. Estimation of genetic parameters using health, fertility and production data from a management recording system for dairy cattle. Anim. Sci. 66, 577-584.

Pryce, J.E., Coffey, M.P. \& Brotherstone, S., 2000. The genetic relationship between calving interval, body condition score and linear type and management traits in registered Holsteins. J. Dairy Sci. 83, 2664-2671.

Pryce, J.E., Royal, M.D., Garnsworthy, P.C. \& Mao, I.L., 2004. Fertility in the high-producing dairy cow. Livest. Prod. Sci. 86, 125-135.

Raheja, K.L., Burnside, E.B. \& Schaeffer, L.R., 1989. Relationship between fertility and production in Holstein dairy cattle in different lactations. J. Dairy Sci. 72, 2670-2678.

Rege, J.E.O., 1991. Genetic analysis of reproductive and productive performance of Friesian cattle in Kenya. J. Anim. Breed. Genet. 108, 412-423.

Royal, M.D., Woolliams, J.A., Webb, R. \& Flint, A.P.F., 2000. Estimation of genetic variation in the interval from parturition to commencement of luteal in Holstein-Friesian dairy cows. J. Repr. Fert. Abstr. Ser. 25. Abstr. 74.

Royal, M.D., Pryce, J.E., Woolliams, J.A. \& Flint, A.P.F., 2002. The genetic relationship between commencement of luteal activity and calving interval, body condition score, production, and linear type traits in Holstein-Friesian dairy cattle. J. Dairy Sci. 85, 3071-3080.

SAS, 1998. Statistical Analysis Systems, Procedures Guide, version 6, $3^{\text {rd }}$ Ed. SAS Institute. Inc., Cary, North Carolina, USA.

Seykora, A.J. \& MacDaniel, B.T., 1983. Heritabilities and correlations of lactation yields and fertility for Holsteins. J. Dairy Sci. 66, 1486-1493.

Tesfa, K.N., 2002. The effect of different milk pricing schemes on a selection index for South African Holstein cattle. M.Sc. thesis. University of the Free State, Bloemfontein, South Africa.

Van Arendonk, J.A.M., Hovenier, R. \& Willem, D.B., 1989. Phenotypic and genetic association between fertility and production in dairy cows. Livest. Prod. Sci. 21, 1-12.

VanRaden, P.M., Sanders, A.H., Tooker, M. E., Miller, R.H., Norman, H.D., Kuhn, M.T. \& Wiggans, G.R., 2004. Development of a national genetic evaluation for cow fertility. J. Dairy Sci. 87, 2285-2292.

Veerkamp, R.F., Koenen, E.P.C. \& De Jong, G., 2001. Genetic correlations among body condition score, yield, and fertility in first-parity cows estimated by random regression models. J. Dairy Sci. 84, 2327-2335. 
Wall, E., Brotherstone, S., Woolliams, J.A., Banos, G. \& Coffey, M.P., 2003. Genetic evaluation of fertility using direct and correlated traits. J. Dairy Sci. 86, 4093-4102.

Wall, E., White, I.S.M., Coffey, M.P. \& Brotherstone, S., 2004. Are high pins related to poor fertility? Interbull bull. 32, 94-98.

Wall, E., Brotherstone, S., Kearney, J.F., Woolliams, J.A. \& Coffey, M.P., 2005. Impact of nonadditive genetic effects in the estimation of breeding values for fertility and correlated traits. J. Dairy Sci. 88, 376-385. 